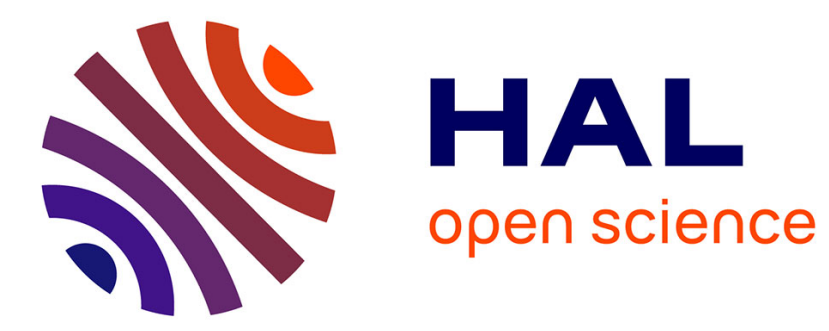

\title{
Green energy from grown at low to high irradiance values, under fed-batch operational conditions
}

Pietro Carlozzi, Cristina Pintucci, Raffaella Piccardi, Arianna Buccioni, Sara

Minieri, Maurizio Lambardi

\section{- To cite this version:}

Pietro Carlozzi, Cristina Pintucci, Raffaella Piccardi, Arianna Buccioni, Sara Minieri, et al.. Green energy from grown at low to high irradiance values, under fed-batch operational conditions. Biotechnology Letters, 2009, 32 (4), pp.477-481. 10.1007/s10529-009-0183-2 . hal-00568369

\section{HAL Id: hal-00568369 \\ https://hal.science/hal-00568369}

Submitted on 23 Feb 2011

HAL is a multi-disciplinary open access archive for the deposit and dissemination of scientific research documents, whether they are published or not. The documents may come from teaching and research institutions in France or abroad, or from public or private research centers.
L'archive ouverte pluridisciplinaire HAL, est destinée au dépôt et à la diffusion de documents scientifiques de niveau recherche, publiés ou non, émanant des établissements d'enseignement et de recherche français ou étrangers, des laboratoires publics ou privés. 
Green energy from Rhodopseudomonas palustris grown at low to high irradiance values, under fed-batch operational conditions

Pietro Carlozzi ${ }^{\mathrm{a}, *}$, Cristina Pintucci ${ }^{\mathrm{a}}$, Raffaella Piccardi ${ }^{\mathrm{a}}$, Arianna Buccioni ${ }^{\mathrm{b}}$, Sara Minieri ${ }^{\mathrm{b}}$, Maurizio Lambardi ${ }^{\mathrm{c}}$

${ }^{a}$ Istituto per lo Studio degli Ecosistemi, Sede di Firenze, Consiglio Nazionale delle Ricerche, Polo Scientifico, Via Madonna del Piano n. 10, 50019 Sesto Fiorentino, Firenze, Italy

${ }^{\mathrm{b}}$ Dipartimento di Scienze Zootecniche, Università degli Studi di Firenze, Via delle Cascine n. 5, 50144 Firenze, Italy

${ }^{c}$ Istituto per la Valorizzazione del Legno e delle Specie Arboree, Consiglio Nazionale delle Ricerche, Polo Scientifico, Via Madonna del Piano n. 10, 50019 Sesto Fiorentino, Firenze, Italy

Corresponding author:

Pietro Carlozzi - Istituto per lo Studio degli Ecosistemi, Sede di Firenze, Consiglio Nazionale delle Ricerche, Polo Scientifico, Via Madonna del Piano n. 10 50019 Sesto Fiorentino, Firenze, Italy. Fax: +39055 5225920 E-mail: p.carlozzi@ise.cnr.it 


\begin{abstract}
Rhodopseudomonas palustris was examined under continuous irradiances of $36,56,75,151$, 320,500 , and $803 \mathrm{~W} \mathrm{~m}^{-2}$, for a co-production of both bio- $\mathrm{H}_{2}$ and biodiesel (lipids). Cultures were grown under fed-batch operational conditions. The highest overall bio- $\mathrm{H}_{2}$ produced $[4.2$ $\left.1\left(\mathrm{H}_{2}\right) 1_{\text {culture }}{ }^{-1}\right]$ was achieved at $320 \mathrm{~W} \mathrm{~m}^{-2}$, while the highest dry biomass $\left(3.18 \mathrm{~g} \mathrm{l}^{-1}\right)$ was attained at $500 \mathrm{~W} \mathrm{~m}^{-2}$. Dry biomass contained between $22 \%$ and $39 \%$ lipid. The total energy conversion efficiency was at its highest $(6.9 \%)$ at $36 \mathrm{~W} \mathrm{~m}^{-2}$.
\end{abstract}

Keywords: green energy; bio- $\mathrm{H}_{2}$; biodiesel; hydrogen production rate; $R$. palustris 


\section{Introduction}

Purple non-sulfur photosynthetic bacteria can decompose organic acids by using light energy and nitrogenase in a photofermentation process (Basak and Das, 2007). Green energies (bioH $\mathrm{H}_{2}$ and biodiesel) needs of cultural systems to be produced. Bioreactor design, hydrodynamic aspects and light distribution are key points to improve $\mathrm{H}_{2}$ yield. Improvements could also be achieved through the genetic modification (Nath and Das, 2004). Chisti (2007) reported: "Biodiesel derived from oil crops is a potential renewable and carbon neutral alternative to petroleum fuels. Unfortunately, biodiesel from oil crops, waste cooking oil and animal fat cannot realistically satisfy even a small fraction of the exiting demand for transport fuels". A review of biodiesel production from oleaginous microorganisms was recently carried out by Ratledge and Cohen (2008). Purple, non-sulfur photosynthetic bacteria, such as Rhodopseudomonas palustris, is able to use irradiance more efficiently than do crop plants, and oil production from bacteria could be improved under adequate or stressed culture conditions.

The purpose of this study is to investigate a co-production of bio- $\mathrm{H}_{2}$ and rich biomass content of lipids for biodiesel production by means of Rhodopseudomonas palustris (strain 42OL) grown at low irradiance $(\mathrm{LI})\left(36,56\right.$ and $\left.76 \mathrm{~W} \mathrm{~m}^{-2}\right)$, at both medium (MI) $\left(151\right.$ and $320 \mathrm{~W} \mathrm{~m}^{-}$ ${ }^{2}$ ) and high irradiance (HI) (500 and $805 \mathrm{~W} \mathrm{~m}^{-2}$ ). The relationship between light intensity and both hydrogen production rate and the total energy conversion efficiency has also been investigated.

\section{Material and methods}

Description of the cultural system

A cylindrical glass photobioreactor [internal diam $=9.6 \mathrm{~cm}$; working volume $(\mathrm{V})=1.07 \mathrm{l}$ ] was held at $30 \pm 0.2{ }^{\circ} \mathrm{C}$. All irradiance was measured at the surface of the photobioreactor using a flat glass surface $(10 \times 16 \mathrm{~cm})$ an averaged from nine different location points. The 
heat exchanger-Plexiglas basin was not filled of water during the irradiance measurements. The average radial depth of water between the Plexiglas (inside wall) and the photobioreactor (outside wall) was $7.3 \mathrm{~cm}$. The gas produced by bacteria was trapped in a graduated glass column (Carlozzi and Lambardi, 2009).

\section{Organism and culture conditions}

Rhodopseudomonas palustris (strain 42OL) was taken from the culture collection of the former Centro di Studio dei Microrganismi Autotrofi of Florence. This centre is now part of the Institute of Ecosystem Study, CNR, Florence - Italy. The bacterium was grown at $30{ }^{\circ} \mathrm{C}$ on a medium previously described in the literature (Carlozzi and Sacchi, 2001), but with glutamic acid at $0.865 \mathrm{~g} \mathrm{l}^{-1}$ and malic acid at $3.26 \mathrm{~g} \mathrm{l}^{-1}$. The initial $\mathrm{pH}$ of the medium was 6.8 . All experiments were carried out under continuous light, at irradiances of $36,56,75,151$, 320,500 , and $803 \mathrm{~W} \mathrm{~m}^{-2}$. The photobioreactor irradiated from one side was operated in a fedbatch mode (Carlozzi and Lambardi, 2009). This feeding strategy was used for long-term investigations $(\max =408 \mathrm{~h})$; otherwise, the yields produced (biomass and $\mathrm{H}_{2}$ ) would have ceased for lack of macronutrients.

\section{Analytical methods}

Dry biomass was determined by using the empirical equation of Carlozzi and Sacchi (2001). Growth was determined from the bacteriochlorophyll (Bchl) concentration (Carlozzi et al., 2006). Cultures were irradiated with a 250 W OSRAM Power-star HQI-TS lamp, and the irradiance was measured using a Quantum/Radiometer/Photometer (model LI-185B, LICOR, Lincoln, Nebraska, USA). In order to determine organic acid concentrations in the bacteria cultures, a HPLC was utilised. After disposable syringe filter units (MFS-13 mm, $0.45 \mu \mathrm{m}$ pore size) were used to remove the cells, the supernatant was tested for malic acid. 
The HPLC was equipped with a C18 analytical column $(250 \mathrm{~mm} \times 4.6 \mathrm{~mm})$ and run at $25^{\circ} \mathrm{C}$. The mobile phase was $0.1 \% \mathrm{H}_{3} \mathrm{PO}_{4}$, at $1 \mathrm{ml} \mathrm{min}^{-1}$.

\section{Gas and lipid evaluation}

The gas mixture produced $\left(\mathrm{CO}_{2}\right.$ and $\left.\mathrm{H}_{2}\right)$ was first made to flow into a basin containing a saline solution absorber of $\mathrm{NaOH}$, which stripped $\mathrm{CO}_{2}$ and then the hydrogen was trapped in a calibrated column, where it was collected and the volume measured to determine hydrogen production. No $\mathrm{CO}_{2}$ was found inside the calibrated column. This was checked by sampling $0.1 \mathrm{ml}$ from the calibrate column and injecting it into a Perkin-Elmer Autosystem gas chromatograph equipped with a thermal conductivity detector (TCD) and a Silica Gel 60/80 Grade 12 column (Alltech, Derfield). The carrier gas was $\mathrm{He}$; pure $\mathrm{H}_{2}$ was used as the standard. Total lipid extraction and the fatty acid profile were determined in accordance with Pushparaj et al. (2008).

\section{Light conversion efficiency}

The total energy conversion efficiency $\left(\eta^{\prime}\right)$ was determined using the following equation:

$$
\eta^{\prime}(\%)=\frac{33.61 \rho_{2} \mathrm{VH}_{2}+\left(\mathrm{P}_{\mathrm{B}}\left(-\Delta \mathrm{P}_{\mathrm{B}}\right)\right)}{\mathrm{I} \mathrm{A} \mathrm{tH}_{2}+\left(\mathrm{MA}_{\mathrm{c}}(-\Delta \mathrm{MA})\right)+\left(\mathrm{GA}_{\mathrm{c}}(-\Delta \mathrm{GA})\right)}
$$

where $\mathrm{\rho H}_{2}$ is the concentration of $\mathrm{H}_{2}\left(\mathrm{~g} \mathrm{l}^{-1}\right)$; $\mathrm{VH}_{2}$ is the volume of $\mathrm{H}_{2}$ produced (l); $\mathrm{P}_{\mathrm{B}}$ is the total biomass produced $(\mathrm{g})$ (ash $=4.5 \%$ of dry biomass; $\left(-\Delta \mathrm{P}_{\mathrm{B}}\right)$ is the heat of combustion of ash-free biomass $(\mathrm{dw})\left(\mathrm{kcal} \mathrm{g}^{-1}\right)$; I is the irradiance $\left(\mathrm{W} \mathrm{m}^{-2}\right)$; A is the irradiated area of the photobioreactor $\left(\mathrm{m}^{-2}\right)$, which was calculated as being $1 / 2$ of the cylindrical reactor surface $\left(2 \pi r_{i} h\right)$, with $r_{i}$ and $h$ indicating, respectively, the internal radius and the height of the cylindrical reactor; $\mathrm{tH}_{2}$ is the evolution time (h); $\mathrm{MA}_{\mathrm{c}}$ is the malic acid consumed ( $\left.\mathrm{g}\right)$; ($\triangle \mathrm{MA})$ is the heat of combustion of MA $\left(\mathrm{kcal} \mathrm{g}^{-1}\right) ; \mathrm{GA}_{\mathrm{c}}$ is the glutamic acid consumed $(\mathrm{g})$, and $(-\Delta \mathrm{GA})$ is the heat of combustion of GA $\left(\mathrm{kcal} \mathrm{g}^{-1}\right)$. 


\section{Results and discussion}

Growth of $R$. palustris and $\mathrm{H}_{2}$ production are shown in Fig. 1. Both bio- $\mathrm{H}_{2}$ and dry biomass productivities and the total energy conversion efficiency versus the irradiance are shown in Fig. 2. The total $\mathrm{H}_{2}$ produced in the photobioreactor (working volume: 1.07 1) increased in accordance with the irradiance up to $4.21\left(\mathrm{H}_{2}\right) 1_{\text {culture }}{ }^{-1}$ at $320 \mathrm{~W} \mathrm{~m}^{-2}$. By increasing the irradiance further, the $\mathrm{H}_{2}$ yield decreased by about $7.5 \%$. The average $\mathrm{H}_{2}$ production rate $\left(\mathrm{HPR}_{\mathrm{av}}\right.$ ) was $12.3 \mathrm{ml} \mathrm{l}^{-1} \mathrm{~h}^{-1} 320 \mathrm{~W} \mathrm{~m}^{-2}$. Chen et al. (2008) predicted an overall $\mathrm{H}_{2}$ photoevolution rate of $12.6 \mathrm{ml} \mathrm{l}^{-1} \mathrm{~h}^{-1}$ by using acetate and butyrate as dual carbon substrates. The yield of $\mathrm{H}_{2}$ achieved in this study was about $33 \%$ higher than that reported by Carlozzi and Lambardi, 2009, and the $\mathrm{H}_{2}$ photoevolution rate was within the range of those cited in the literature for use of the same microorganism species (Chen et al., 2006; Eroğlu et al., 2008). The highest cumulative $\mathrm{H}_{2}$ was achieved at $320 \mathrm{~W} \mathrm{~m}^{-2}$, while the highest dry biomass was attained at $500 \mathrm{~W} \mathrm{~m}^{-2}$. This was because the biomass production competed with the $\mathrm{H}_{2}$ photoevolution.

The total energy conversion efficiency was at its highest $(6.9 \%)$ at $36 \mathrm{~W} \mathrm{~m}^{-2}$, and went progressively down as the irradiance increased. In 2009, Obeid et al. wrote: "The conversion efficiency of light energy to hydrogen is the key factor in the development of a biological process devoted to hydrogen production". The $\eta^{\prime}$ of $6.9 \%$ is a mong the highest values cited in the literature (Kondo et al. 2006; Basak and Das, 2009).

Biomasses of $R$. palustris harvested at the end of each fed-batch cycle, during bio- $\mathrm{H}_{2}$ photoevolution, were analysed in order to determine the total lipid content. The results are shown in Fig. 3. The lipid content 36-39\% of the dry biomass when the irradiance was within the 56-151 $\mathrm{W} \mathrm{m}^{-2}$ range. A further increase in the irradiance caused a relevant and progressive drop in the lipid content in the R. palustris biomasses: the minimum content (22 $\%$ ) was reached when the irradiance was at its highest $\left(803 \mathrm{~W} \mathrm{~m}^{-2}\right)$. With an irradiance of less 
than $56 \mathrm{~W} \mathrm{~m}^{-2}$, the lipid content of the biomass dry weight also decreased. The major fatty acid of $R$. palustris grown inside a tubular underwater photobioreactor (UwTP) (Carlozzi and Sacchi, 2001) were 16:0 (17\%); 16:1 (7\%); 18:1 (73\%); 18:0 (3\%). Our data are similar to the four R. palustris strains cited by Imhoff and Bias-Imhoff (1995). Co-production of both bio- $\mathrm{H}_{2}$ and biodiesel, as biofuels, is proposed in this study. For biodiesel production, triglycerides are transeterified with methanol. The reaction occurs stepwise: triglycerides are first converted to diglycerides, then to monoglycerides, and lastly to glycerol + methyl esters (biodiesel) (Chisti 2007). The author listed fourteen microalgal species with their respective oil contents. The oil content we found in $R$. palustris biomasses can be included in the group of the five microalgal species, with the highest oil content, reported by Chisti (2007). Bacteria accumulate fewer lipids than do microalgae, and the average oil content is about 20$40 \%$ of the dry biomass (Meng et al., 2009). Microorganisms that can accumulate lipids at more than $20 \%$ of their biomass are defined as oleaginous species (Ratledge and Wynn, 2002). Since the lipid content of the $R$. palustris, that we investigated was within the range of 22-39\% of the dry-biomass, we could define our bacteria strain as began an oleaginous species. Carlozzi and Sacchi (2001) reported, outdoors, a production of $R$. palustris dry biomass of $64 \mathrm{~g} \mathrm{~m}^{-2}$ day $^{-1}$. On the basis of Carlozzi's investigations, a projection of the monthly oil production over the years can be made from $R$. palustris grown outdoors in the climatic conditions of Florence, Italy (latitude $43^{\circ} 46^{\prime} \mathrm{N}$, longitude $11^{\circ} 15^{\prime}$ E) (Fig. 4). Projections on bio- $\mathrm{H}_{2}$ production, outdoors, were not carried out, because we did not have enough experimental results, even though a first, very short investigation has recently been Fig. 4 carried out (Carlozzi et al., 2008). To reduce the greenhouse gas effect, oil production (biodiesel) from plants, crops, microalgae, yeast and, recently, bacteria has already been suggested (Ratledge and Wynn, 2002; Chisti, 2007; Rittmann, 2008). Nevertheless, we would remark that this was the first time, which a non-sulfur photosynthetic bacteria (R. palustris) has been proposed as a potential oil source for biodiesel production. 


\section{Acknowledgements}

We wish to thank Edoardo Pinzani for his management of the cultural system and Angelo Sacchi and Sandro Dodero for their technical assistance.

\section{References}

Basak N, Das D (2007) The prospect of purple non-sulfur (PNS) photosynthetic bacteria for hydrogen production: the present state of the art. World J Microbiol Biotechnol 23:31-42

Basak N, Das D (2009) Photofermentative hydrogen production using purple non-sulfur bacteria Rhodobacter sphaeroides O.U.001 in an annular photobioreactor: a case study. Biomass Bioenergy 33:911-919

Carlozzi P, Lambardi M, Pushparaj B et al (2008) Indoor and outdoor photobiological hydrogen production by Rhodopseudomonas palustris, strain 42OL. Current Topics Biotechnol 4:93-100

Carlozzi P, Lambardi M (2009) Fed-batch operation for bio- $\mathrm{H}_{2}$ production by Rhodopseudomonas palustris (strain 42 OL). Renew Energy 34(12):2577-2584

Carlozzi P, Pushparaj B, Degl'Innocenti A et al (2006) Growth characteristics of Rhodopseudomonas palustris cultured outdoors, in an underwater tubular photobioreactor and investigation on photosynthetic efficiency. Appl Microbiol Biotechnol 73:789-795

Carlozzi P, Sacchi A (2001) Biomass production and studies on Rhodopseudomonas palustris grown in an outdoor, temperature controlled, underwater tubular photobioreactor. $\mathbf{J}$ Biotechnol 88:239-249

Chen CY, Lee CM, Chang JS (2006) Hydrogen production by indigenous photosynthetic bacterium Rhodopseudomonas palustris WP3-5 using optical fiber-illuminating photobioreactors. Biochem. Eng J 32:33-42 
Chen CY, Lu WB, Liu $\mathrm{CH}$ et al (2008) Improved phototrophic $\mathrm{H}_{2}$ production with Rhodopseudomonas palustris WP3-5 using acetate and butyrate as dual carbon substrates. Biores Technol 99:3609-3616

Chisti Y (2007) Biodiesel from microalgae. Biotechnol Adv 25:294-306

Eroğlu I, Tabanoğlu A, Gündüz U et al (2008) Hydrogen production by Rhodobacter sphaeroides O.U.001 in a flat plate solar bioreactor. Int J Hydrogen Energy 33:531 -541

Imhoff JF, Bias-Imhoff U (1995) Lipids, quinones and fatty acids of anoxygenic phototrophic bacteria. In: Blankenship RE, Madigan MT, Bauer CE (eds) Advances in Photosynthesis: Anoxygenic Photosynthetic Bacteria. Kluwer Academic Publisher. Dordrecht, The Netherlands

Kondo T, Wakayama T, Miyake J (2006) Efficient hydrogen production using a multilayered photobioreactor and a photosynthetic bacterium mutant with reduced pigment. Int J Hydrogen Energy 31:1522-1526

Meng X, Yang J, Xu X et al (2009) Biodiesel production from oleaginous microorganisms. Renew Energy 34:1-5

Nath K, Das D et al (2004) Improvement of fermentative hydrogen production: various approaches. Appl Microbial Biotechnol 65:520-529

Obeid J, Magnin J-P, Flaus J.M et al (2009) Modelling of hydrogen production in batch cultures of the photosynthetic bacterium Rhodobacter capsulatus. Int J Hydrogen Energy $34: 180-185$

Pushparaj B, Buccioni A, Paperi R et al (2008) Fatty acid composition of antarctic cyanobacteria. Phycologia 47(4):430-434

Ratledge C, Cohen Z (2008) Microbial and algal oils: Do they have a future for biodiesel or as commodity oils? Lipid Technol 20(7):155-160

Ratledge C, Wynn JP (2002) The biochemistry and molecular biology of lipid accumulation in oleaginous microorganisms. Adv Appl Microbiol 51:1-51 
Rittmann BE (2008) Opportunity for renewable bioenergy using microorganisms. Biotechnol Bioeng 100(2):203-212

\section{Figure captions}

Fig. 1. Trends of bacteriochlorophyll (Bchl) synthesis versus time attained with $R$. palustris grown at low (A), middle (B) and high irradiance. Values are means of three replications \pm standard deviation.

Fig. 2. Bio- $\mathrm{H}_{2}$ and dry-biomass productivities and the total energy conversion efficiency achieved at seven different irradiances $\left(36,56,75,151,320,500\right.$ and $\left.803 \mathrm{~W} \mathrm{~m}^{-2}\right)$. Bars \pm standard deviation.

Fig. 3. Lipid content in dry-biomass of $R$. palustris grown from 36 to $803 \mathrm{~W} \mathrm{~m}^{-2}$ during hydrogen photo-evolution. Values are means of three replications \pm standard deviation.

Fig. 4. (A) Solar radiation and (B) predicted results of the monthly oil production from $R$. palustris grown outdoors in the climatic conditions of Florence, Italy (latitude: $43^{\circ} 46^{\prime}$ $\mathrm{N}$; longitude: $11^{\circ} 15^{\prime} \mathrm{E}$ ). Bars \pm standard deviation. 

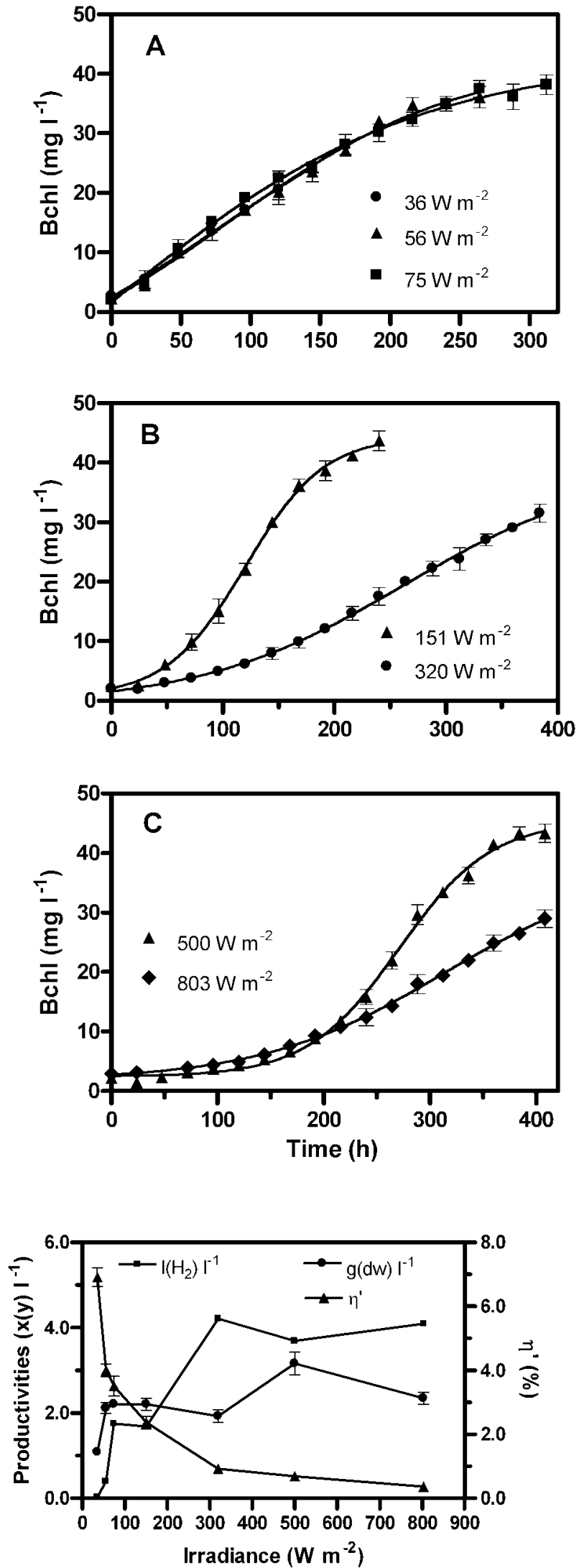

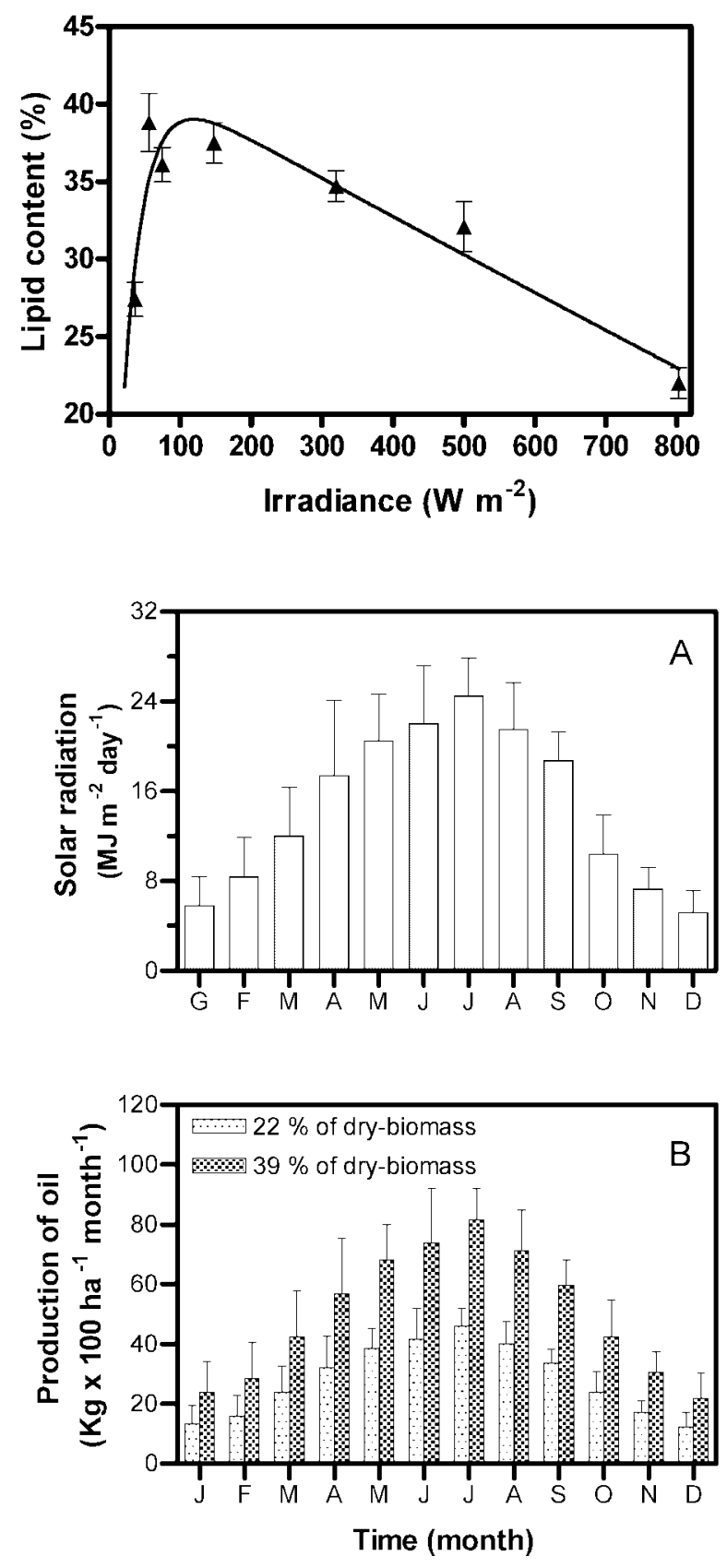